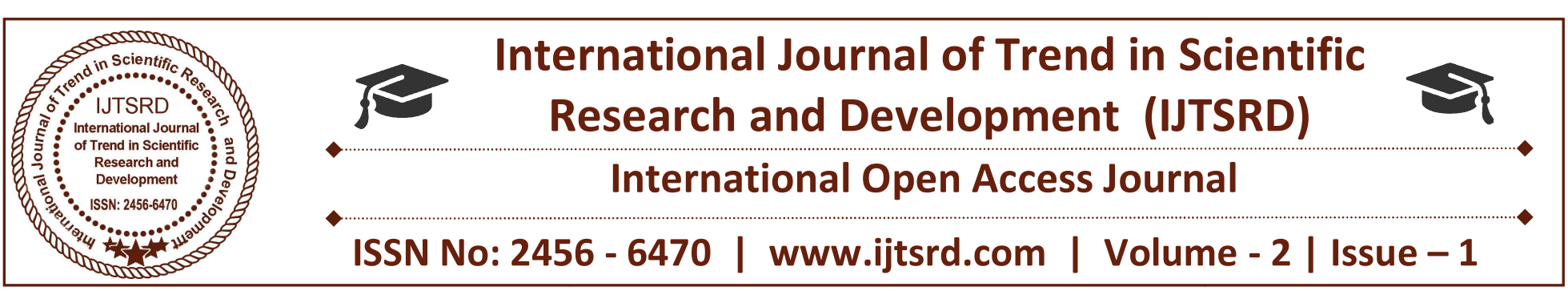

\title{
Role of Financial Institutions for the Development of Women Entrepreneurship in India
}

\author{
Dr. N. Rajendhiran \\ Professor \\ PRIMS, Periyar University, Salem, Tamil Nadu, India
}

\author{
M. Kousalya Devi \\ Research Scholar \\ PRIMS, Periyar University, Salem, Tamil Nadu, India
}

\begin{abstract}
Entrepreneurship as an factor of economic development is now recognized. A number of financial institutions provide support to women entrepreneurs for their innovative and imaginative scheme of activities aimed at skill development for income and employment generation in different sectors. Besides, the society should also facilitate the growth of women by recognizing their talents and abilities. There has been a substantial growth in women's involvement in the economic activities all over the world over the past few decades. For this both the government and nongovernment agencies have to play a vital role. Despite the efforts of governmental and non-governmental organizations, the women entrepreneurs are facing many problems. It has been pointed out by many research studies that more than $70 \%$ of the problems faced by the women entrepreneurship are related with credit. Financial institutions have historically viewed women entrepreneurs as more doubtful preposition than men entrepreneurs.
\end{abstract}

Today there is a greater development among women. If given the opportunity, they will deliver the outcome. It is therefore essential to encourage educated young women to entrepreneurial streams with financial, technical and scientific assistance. Hence, an integrated approach is necessary for making the movement of women entrepreneurship a success. Governmental and Non-governmental organizations should make more focused and directed efforts, and initiate specific programmes for women entrepreneurship development. Entrepreneurial development programmes should train, motivate, enhance and shape-up individual skills of women having market potential. The EDPs and MDPs can become a vital link for harnessing huge and unused human skills to channelize them towards accelerating the gender mainstreaming and position women entrepreneur on equivalence with men entrepreneurs.

Keywords: Financial Institutions; development; women Entrepreneur; government

\section{INTRODUCTION}

Entrepreneurship as an ingredient of economic development has been recognized long ago in 1950. It was since then substantial amount of research has gone into this sphere. It is well known fact that entrepreneurs are born but they can also be made through innovative and creative interventions. However men and women at large are not showing sufficient of entrepreneurship skills and the women's position is more critical. Therefore, they should be helped particularly where women entrepreneurs are prone to face more hurdles.

The focus on the contribution of women in direct productive work was first brought out in 1970 by Ester Boserup in his book "Women's Role in Economic Development". This work of Boserup is a complication of his research experience in India. It also provided a conceptual framework for research on Women and Development. Around the mid 1970's, neo-Marxist feminists and dependency theorists began looking at the relationship between women and development ratherthan the strategies for integrating women in economic development. However, lack of understanding of women's work in developing societies, and Western biases in development projects 
reinforced the division between public and private spheres of women lives.

Women and development like women in development focused on productive sector, and aimed at skill development for income generation.

\section{Financial Institutions:}

A number of institutions collect funds from the public and place them in financial assets such as deposits, loans and bonds rather than tangi property. Various financial institutions and banks are playing a significant role in the development of women entrepreneurship. Some of them are described below Governmental Institutions: Regional Rural Bank, Cooperative Societies, Khadi and Village Industries, National Agriculture Bank for Rural and Development operate in rural areas whereas National Small Business Development Corporation, Research Development Corporation, National Institute for Entrepreneurship operates in urban areas. However, Small Industries Development Corporation, National Small Industries Corporation, Small Industries development of India, Industrial financial Corporation of India functions in rural as well as urban areas. Tiwari et al (1981) found that the government was assisting the women for entrepreneurship development by providing financial assistance in the form of term loans, interest, subsidy, unsecured loans and concession in the form of subsidies in the capital, self employment loan etc. Kumar (1998) reported from Banglore that Canara Bank's Centre for Entrepreneurship Development gives training to women and helps them to set up small industrial units besides providing assistance for marketing their product. The assistance by the government to women entrepreneurship has been provided through various institutions like SIDO, DIC, EDI, NAYE, NISIET, SIDBI, SEF, WCFC and commercial banks etc.

\section{Non- Governmental Institutions:}

World Assembly of Small and Medium Entrepreneurs, Xavier Institute for Social Societies are functioning in rural areas whereas National Association of Women Entrepreneurs and Executives, Indian Council of Women Entrepreneurs is working in urban areas. National Alliance of Young Entrepreneurs, Self Employed Women's Association etc are having their presence in rural as well as urban areas.

There are many promotional governmental and nongovernmental institutes/agencies functioning at national level for the promotion of entrepreneurship. These are also playing significant role in the development of women entrepreneurship.
3. Financial Schemes for Women Entrepreneurship:

With a view that women entrepreneurs should come forward in industrial field and become self- sufficient, governmental and financial institutions have announced many schemes of providing financial assistance. Seed apital Scheme- In order to start one's own business this scheme is undertaken by the government. Mohanty (2004) suggested that various self employment and income generating schemes such as IRDP, SEEUY, PMRY, SSI, KVI and DWCRA implemented in Orissa have made significant contribution towards economic empowerment and self- employment of women and development of women entrepreneurship.

\section{Important government agencies are Directorate of Industries:}

Khadi and Village Industries Board, Small Industries Service Institutions, Mahila Vikash Sambaya Nigam and Rashtriya Mahila Kosh were contacted for this purpose. The Rastriya Mahila Kosh mainly fulfills the credit needs of poor women particularly, those engaged in the unorganized sector not being adequately addressed by the formal financial institutions. RMK aims at promoting small enterprises among poor women through provision of credit as an instrument to socio-economic change and development through the provision package of financial and social development service for the development of women entrepreneurship. Gupta (1997) found that the empowerment of women central government of India has started Priyadarshani Yojna in the name of late Prime Minister Smt. Indira Gandhi. Through this scheme loan on minimum interest is provided to women for entrepreneurship development to improve their livelihood. As a pilot project this scheme has been launched in six districts: four districts (Raipur, Sitapur, Shravasti and Behraich) are in Uttar Pradesh and two (Sitamani and Madhubani) in Bihar.

\section{a. Obstacles in Getting Financial Assistance by Institutions:}

Despite the efforts of governmental and nongovernmental organization the women entrepreneurs are facing lots of problems. In various studies it was reported that more than $70 \%$ of the problems faced by the women entrepreneurs are related with credit.

\section{objective of the study:}

The main objective of this study is to investigate the involvement of financial institutions in the development of women entrepreneurship in Tamil Nadu. 
$>$ to provide financial, technical, social and business support to women entrepreneurs

$>$ Women entrepreneurship has been recognised as an important source of economic growth.

$>$ Women's entrepreneurship can make a strong the economic well-being of the family and communities, poverty reduction and women's empowerment in Tamilnadu.

\section{b. Policies and Schemes for Women Entrepreneurs in India:}

In India, the Micro, Small \& Medium Enterprises development organisations, various State Small Industries Development Corporations, the Nationalised banks and even NGOs are conducting various programmes including Entrepreneurship Development Programmes (EDPs) to cater to the needs of potential women entrepreneurs, who may not have adequate educational background and skills. The Office of DC (MSME) has also opened a Women Cell to provide coordination and assistance to women entrepreneurs facing specific problems.

There are also several other schemes of the government at central and state level, which provide assistance for setting up training-cum-income generating activities for needy women to make them economically independent. Small Industries Development Bank of India (SIDBI) has also been implementing special schemes for women entrepreneurs.

In addition to the special schemes for women entrepreneurs, various government schemes for MSMEs also provide certain special incentives and concessions for women entrepreneurs. For instance, under Prime Minister's Rozgar Yojana (PMRY), preference is given to women beneficiaries. The government has also made several relaxations for women to facilitate the participation of women beneficiaries in this scheme. Similarly, under the MSE Cluster Development Programme by Ministry of MSME, the contribution from the Ministry of MSME varies between $30-80 \%$ of the total project in case of hard intervention, but in the case of clusters owned and managed by women entrepreneurs, contribution of the M/o MSME could be upto $90 \%$ of the project cost. Similarly, under the Credit Guarantee Fund Scheme for Micro and Small Enterprises, the guarantee cover is generally available upto $75 \%$ of the loans extended; however the extent of guarantee cover is $80 \%$ for MSEs operated and/ or owned by women.

c. Development of Women Entrepreneurship Through Financial Institutions in India:
Women entrepreneurship has been recognised as an important source of economic growth. Women entrepreneurs create new jobs for themselves and others and also provide society with different solutions to management, organisation and business problems. However, they still represent a minority of all entrepreneurs. Women entrepreneurs often face genderbased barriers to starting and growing their businesses, like discriminatory property, matrimonial and inheritance laws and/or cultural practices; lack of access to formal finance mechanisms; limited mobility and access to information and networks, etc.

Women's entrepreneurship can make a particularly strong contribution to the economic well-being of the family and communities, poverty reduction and women's empowerment, thus contributing to the Millennium Development Goals (MDGs). Thus, governments across the world as well as various developmental organizations are actively undertaking promotion of women entrepreneurs through various schemes, incentives and promotional measures.

Women entrepreneurs in the four southern states and Maharashtra account for over $50 \%$ of all women-led small-scale industrial units in India.

\section{d. Loans for Women:}

Not only if you are a businessman can apply or get a loan, but in India, women are equally entitled to get business loan. There are not many women with the knowledge, to take advantage of loans offered by public sector banks. Indian business women are still a minority. The awareness among women about loan products to set up small enterprise is extremely low. However, things have definitely changed over last 25 years since the time the first business loan scheme was introduced exclusively for women. A few Indian Public Sector Banks( PSBs) play an important role. State Bank of India (SBI) Stree Shakti package scheme was introduced withthe aim to get loans for women who are keen to start-up a business. Punjab National Bank (PNB) also runs a scheme Mahila Udyam Nidhi Scheme which is beneficial in a same concern.

4. The business loan through such schemes is possible only as in when women fulfill the following conditions:

A woman or the housewife must be aged 18 years or above, must have lived in a place for more than six months, she must not have been a member of any industrial cooperative society and not indebted to any cooperative or state agency. Saving fund account with the bank is a must. In which she has to deposit 
fortnightly an amount after her working and living expenses.

You are ready to start your business but the knowhow to take loan is still a question.Indian nationalized banks offer loan schemes through which women can start-up new scale of manufacture, preservation, and processing of goods.

Bank of India's, Priyadarshini Yojana scheme, no collateral security is required for loans up to Rs 5 lakh and for small-scale industries (SSI) units and there is a relief of interest rates from $0.5 \%$ to $1 \%$. Similarly, Oriental Bank of Commerce's Orient Mahila Vikas Yojana scheme, there is upto $2 \%$ concessions and no collateral security for loans upto Rs. 10 lacs and in case of SSI no collateral security required up to Rs.25 lacs.

So, it is advisable that they should explore more before starting a new business assignment as there are many banks those not only provide special counseling for women entrepreneurs but also offer training how to market their products.

Women entrepreneurs face many difficulties to get ahead their life in business and are suffering from insufficient financial resources and working capital which leads to lack their external funds. However, knowledge of technical changes, new market trends, participation in decision making, and education can always be a plus point to run a business.

To conclude, government should bring in more and better facilities and schemes to motivate women to engage in small scale businesses.Right efforts from all areas can be a key factor for the development of women entrepreneur which leads to their active participation and knowledge in business activities.

\section{India's private and state-run banks have several schemes targeting women entrepreneurs. This article lists 16 schemes from nine banks, sourced from SIDBI's entrepreneurship:}

\section{a. State Bank of Mysore:}

Stree Shakthi Package for Women Entrepreneurs: Financial assistance is earmarked for enterprises where a woman owns a majority stake, which is over and above 51percent equity in the firm. Women entrepreneurs who have participated in state-sponsored EDPs or programs co-sponsored / sponsored by SBM are eligible to apply for financial assistance.

\section{b. State Bank of Hyderabad}

Stree Shakti Package: The bank encourages entrepreneurship among women by offering some concessions and special facilities that help train women entrepreneurs.

\section{c. Punjab National Bank:}

PNB Mahila Udyam Nidhi Scheme: Targets the micro and small scale sector as well as the rehabilitation of sick SSI units.

$>$ PNB Mahila Samridhi Yojna: Financial aid for the purchase of infrastructure for tailoring shops, boutiques, telecom agencies, beauty parlours, and Internet browsing centers. Scheme For Financing Creches: Provides cheaper and easier credit to setup a crèche. Equipment such as stationery, refrigerators and water filters are covered by the scheme.

$>$ PNB Kalyani Card Scheme: It targets both literate and illiterate women hailing from the semi-urban or rural areas looking to agriculture / non-farm activities.

> PNB Mahila Sashaktikaran Abhiyan: Provides concessions such as a reduction in interest rates; waiver of 50 percent of the upfront fee and margin fee cap at 10 percent

\section{d. Punjab and Sind Bank:}

P\&S Bank Udyogini Scheme: Targets micro and small scale manufacturing units; the retail sector; the agriculture sector, among others

\section{e. Oriental Bank of Commerce:}

> Scheme for Professional \& Self-Employed Women: Provides term loans for the purchase of fixed assets; apart from working capita.1

> Scheme for Beauty Parlors / Boutiques / Saloons and Tailoring: Provides 'easy, timely and convenient access' to institutional credit.

Oriented Mahila Vikas Yojana: Provides need based credit needs for women entrepreneurs.

\section{f. State Bank of Travancore:}

Mahila Vikas Scheme: Provide term loans / working capital to units promoted by women entrepreneurs. The woman entrepreneur must own a majority stake and the half the employees have to be women

\section{g. Dena Bank}

Dena Shakti Scheme for Women Entrepreneurs: The scheme covers agriculture and allied activities; small 
enterprises (direct and indirect Finance); micro and small (manufacturing) enterprises; micro and small (service) enterprises which include small road and water transport operators, small business professional and all other service enterprises; retail trade; micro credit; education; and the housing sectors

\section{h. Bank of Baroda}

Akshaya Mahila Arthik Sahay Yojna: Provides financial assistance for those into retail trade and agricultural activities

\section{i. Andhra Bank}

ALEAP \& CGTSI - Mutual Credit Guarantee Scheme for Women: Provides credit facilities (fund based and/ or non-fund based) of up to Rs.100 lakh (both manufacturing and service sectors) without any collateral security and /or third party guarantee. Retail trade is excluded

highly confident about starting their own businesses,

\section{Women Entrepreneur Cell:}

\begin{tabular}{|c|c|c|}
\hline S.no & Particulars & Women Entrepreneur Cell \\
\hline 1 & Vision & $\begin{array}{l}\text { Emerge as a key player for Women Empowerment by enhancing their capabilities in } \\
\text { Entrepreneurship ,responsive to their special credit needs, offering them best financial } \\
\text { services and best banking practices. }\end{array}$ \\
\hline 2 & Objectives & $\begin{array}{l}\text { To cater women entrepreneurs at all level of Economic activity with emphasis on } \\
\text { MSME, Agriculture and retail in sinc with Govt. priorities. } \\
\text { To identify , encourage and assist aspiring Women Entrepreneurs to start an } \\
\text { Enterprise professionally. } \\
\text { To guide and support existing women entrepreneurs in expansion and } \\
\text { modernization of their unit. } \\
\text { To co-ordinate with Government / non Government women's organisations / } \\
\text { Associations to bring more and more Women Entrepreneurs into bank's fold. }\end{array}$ \\
\hline 3 & Functions & $\begin{array}{l}\text { Close liaisoning with various Government depts. specially MSME dept. and } \\
\text { departments dealing with women issues at Centre, State, District and Taluka level. } \\
\text { Organizing Workshop / training sessions to sharpen their skill in the field of Business } \\
\text { finance, marketing strategies, management techniques etc. } \\
\text { Counselling in Preparation of project reports choosing right loan product in tune with } \\
\text { credit needs, Market survey \& external credit rating. } \\
\text { Career Guidance Programmes' and workshops on 'Emerging entrepreneurial } \\
\text { Opportunities' for college students . } \\
\text { Preparation of data base -Business women directory for women entrepreneurs to } \\
\text { develop linkage and network essential for business growth . } \\
\text { Marketing support to women entrepreneurs by arranging exhibition cum sale of } \\
\text { products manufactured by them. } \\
\text { Organizing SHG awareness programmes, assistance in formation of SHGs, credit } \\
\text { linkage and trainings, identification of area specific viable income generating projects . } \\
\text { Design women special credit products to generate self employment. } \\
\text { Formulation of policy guidelines related to credit delivery to women Entrepreneurs. }\end{array}$ \\
\hline 4 & $\begin{array}{l}\text { Organisational } \\
\text { Setup }\end{array}$ & $\begin{array}{l}\text { WEC is established at the Bank's Corporate Office, Mumbai on the auspicious day of } \\
8^{\text {th }} \text { of March } 2013 \text { being International Womens day with an objective of assisting the } \\
\text { potential women entrepreneurs to select income generating activities and start ventures } \\
\text { of their own. Now } 93 \text { Nodal Officers are functioning at all Zonal Offices and } \\
\text { Regional Offices of the Bank across the country with a monitoring cell at the } \\
\text { Corporate Office, Mumbai . } \\
\text { At corporate office, Mumbai WEC is being headed by a woman Asst General } \\
\text { Manager under supervision and overall direction of General Manager MSME Dept. }\end{array}$ \\
\hline
\end{tabular}




\section{Financial assistance for women:}

It is estimated that women entrepreneurs comprise about 10 per cent of the total entrepreneurs in India. However, it is not late before this percentage doubles and women come out in large numbers to start up their own business ventures. There has also been a lot of discussion from time to time to empower women and promoting women entrepreneurs. Various banks and institutions extend their financial support in the form of incentives, loans, schemes etc. to aspiring women entrepreneurs. The Government of India, on its part has also implemented a Scheme, namely, "Trade Related Entrepreneurship Assistance and Development (TREAD) to encourage women in setting up their own ventures.

\section{a. Schemes offered to women entrepreneurs:}

Dena Bank under the Dena Shakti scheme promotes women entrepreneurship by funding a number of activities and giving a concession of $0.25 \%$ on interest rate. The scheme initially covered only the manufacturing sector, but it has now been extended to agriculture and allied activities, small enterprises, micro and small (manufacturing and service) enterprises, retail trade, micro-credit, education and housing. Dena Bank. Mahila Udyam Nidhi Scheme (MUN) run by SIDBI provides equity type of assistance to women entrepreneurs for setting up new industrial venture with the project cost upto Rs. 10 lac in small scale sector.

Punjab \& Sind Bank's Udyogini Scheme encourages women entrepreneurs to avail the loans on liberal terms and exclusive catering of credit under Direct agriculture activities, Tiny SSI sector, Business enterprises, Retail traders, Professional and Self employed etc.

\section{Challenges for a woman entrepreneur:}

Limitations abound when it comes to starting any kind of business by a woman, particularly in a country where women have always been looked down upon. A woman besides being weighed down by family and societal pressure, lack of financial assistance is one of the biggest challenge that she needs to face. Finance is the lifeblood of any enterprise and in absence of adequate financial aid, it becomes invariably impossible for any business to sustain.

Women entrepreneurs are believed to stiffer a lot in raising and meeting the financial needs of their businesses. Adding to their woos, bankers, creditors and financial institutes are also never too much willing to provide financial assistance to women borrowers.
They cite their lack of credit worthiness and business acumen as the main reason for their unwillingness.

Though a number of credit schemes are available for women, low awareness about these available schemes impedes many women in realising their dream of becoming an entrepreneur. Another major concern is that of banks providing only a minor relief in terms of interest rate. The other terms and conditions of the schemes happen to be similar to consumer loans. Also, the higher the loan amount, the more difficult it is to get loans. Bank officials often get skeptical when a woman comes asking for a loan of a higher amount to start a business. It also becomes a challenging task for a woman to convince a bank official about her business plan and that she would not default on the loan granted by the bank.

\section{The reasons behind the trend}

The rise in education among women, rising level of male-female equality, rise of general awareness and independence among women are some of the major reasons.

Ruchita Shah of OyeChotu, Ahmedabad, believes that equal parenting, a sub-product of the rising gender equality, is also a contributing factor. However, she says, this trend is more noticeable in the metros.

Jessica Gupta of the Mumbai-based Secret Wardrobe feels that 'easy access to information through the web world' is an important reason behind this rise. Ruchira Bhatia of Saundhi_Mitti concurs. "The digital boom has led to opening up of sectors of great interest to women, like fashion, home decor, arts and crafts and cooking, which has allowed women to try and create a business out of their hobbies and interests," Ruchira states.

"Career women across the country are realising that there is an alternative to a full-fledged job that allows greater flexibility and greater fulfilment of individual aspirations," says Ruchira. "Among housewives, too, realisation is dawning that life after marriage and/or children need not mean only full-time homemaking/childcare, and that they can also become entrepreneurs," she states.

Jayanti (Jonty) Rajagopalan of Detours Hyderabad states, "One reason is the increasing number of women working for a living and their growth in the corporate sector. This gives them the confidence to start their own business." "It can also be due to men being more supportive with the idea of their partners doing something 'risky' while they get home a regular income," Jonty avers. 


\section{Being a woman entrepreneur in India:}

All the women entrepreneurs we talked to were of the opinion that there an number equal opportunities available to them as they are to male entrepreneurs. The playing field appears to be level in this regard in India.

"So far, the response has been encouraging," says Jessica, conceding that this could be because her business is part of the fashion segment, which is naturally seen as a 'woman's forte'. "Being a woman has never posed any hurdle in developing my business as such," she states.

Ruchira states that she has not faced any hurdles specific to 'women' entrepreneurs, and one major reason for this is that she has a very supportive family, which allowed her the freedom to become an entrepreneur. "Perhaps, a lot of women find this a big stumbling block," she states.

"Apart from family constraints, I cannot imagine a single reason why being a woman entrepreneur would be any more difficult than being a man entrepreneur, unless the field chosen is traditionally male-dominated or, in other ways, tough for women," states Ruchira.

"I would not say being a woman entrepreneur is easy in India. There is still a segment of people who take women for granted and expect 'out-of-business' activities from women," says Ruchita. However, this is rapidly changing, she says.

\section{Discussion about The best and worst of being a woman entrepreneur:}

"You do tend to get noticed more as a woman entrepreneur, because people still consider a woman starting a business as something out of the ordinary. In some ways, I guess it is good because you get written about, and that means PR!," Jonty says.

"However, the fact that women entrepreneurs are still seen as being unusual is, in itself, a problem for me. It will take many more years for her to be seen as just another person starting something on her own. Till then, we have to live with the good and the bad that comes with it," quips Jonty.

"I think a lot also depends on the industry you are in," she states.

"An issue here could be that given how difficult it is to get started, a lot of women may be forced to reassess their ability to become an entrepreneur, because it means more money being spent, more time away from home, more support needed from family," Ruchira says.
"The best part of being an Indian woman entrepreneur is that these days, you constantly get to hear of other women who are starting or doing really well in their own ventures, and this is a great motivating factor," states Jessica.

"The worst part is that you still come across judgmental people who assume that just because you successfully run your own venture, you must be neglecting your family for your work," Jessica quips. Jonty and Ruchita share her opinion on this.

\section{Suggestions and Recommendations for Women Entrepreneurs:}

"It is tougher for a woman entrepreneur to achieve a work-family business. It is, therefore, key to effectively divide responsibilities among your partner(s) or employees," says Jessica.

"It is good to have an adequate support system at home," she adds.

"Confidence and networking will always reap positive results," states Ruchita.

Jonty states that it is important to understand that men and women make decisions differently, and thus, have different ways of running their business. "We tend to make decisions with a combination of the heart and the head. My advice would be to continue doing that. It is a strength and not a weakness," she states.

"Choose your team wisely - have people who respect you and complement you," Jonty adds.

"Get your hands dirty," advises Ruchira. "Get in touch with other entrepreneurs in your space, and discuss openly and freely," she adds.

For the proper development of women Entrepreneurship in India, we have to evolve into much more 282 Indian Research Journal of Extension Education Special Issue (Volume I), January, 2012 strategies to suit the various conditions in different communities and regions.

11. The various problems being confronted by women entrepreneurs can be solved in the following manner:-

\section{a. Uneven}

Ministries of finance and Central banks can play akey role in encouraging competition among anumber of financial institutions with in their country. 
$>$ Government can also play a key role in promoting flexibility regarding collateral.

$>$ Financial institutions must recognize the potential of women entrepreneurs and develop special services for them.

$>$ Proper technical education to the women.

\section{b. Improvement of identification mechanism of newwomen entrepreneurs.}

$>$ Engaged organizations and agencies in EDPs should co-ordinate their activities effectively.

$>$ Assistance to project formulations.

$>$ Availability of adequate infrastructures to the women.

$>$ Free training facilities in the field of enterprises.

$>$ Avoid delaying attitudes by different EDP institutions.

$>$ Better co-ordination between financial institutions and women entrepreneurs.

$>$ For developing a proper co-ordination between executives of promotional agencies and viable women entrepreneurs.

$>$ Adequate data regarding market situation should be made available to the women entrepreneurs.

$>$ Adequate follow- up support to the women entrepreneurs.

The task ahead for EDP institutions is to communicate the noble message of women entrepreneurship development in most effective manner among the women aspirants of all regions and all classes. In the last, to ensure women entrepreneurship development, integrated efforts by various organization and agencies are needed so that necessary assistance should be provided to prospective as well as existing women entrepreneurship.

\section{Conclusion:}

Entrepreneurship as an factor of economic development is now recognized. A number of financial institutions provide support to women entrepreneurs for their innovative and imaginative scheme of activities aimed at skill development for income and employment generation in different sectors. Women entrepreneurs have tasted adequate amount of success in carving a position for themselves. Nevertheless, the myth that financing a woman run business is a big risk still persists. They are still under the notion that women entrepreneurs can never handle pressure as great as men and this would eventually mean only failure. It is only when people come out of this legend will woman entrepreneurs thrive and they would be able to contribute to the economic development of the country and come with equivalence with that of their male counterparts.

\section{References:}

1) Charumathi, B.(1991): Women Entrepreneur's Challenges and Prospects, Head Department of Management, Karpagarn Arts and Science College Affiliated to Bharthiar University, Coimbatore, 1991, p.57.

2) Pal, M.S. (1997): Women Entrepreneurship and the Need for Financial Sector Reform. Economic Reform Today, September, 1997, 8, p.26-29.

3) Gupta, C.G. and Srinivasan, N.P. (1997): Women Entrepreneurship and the Need for Financial Sector Reform. Economic Reform Today, September, 1997, 8, p.30.

4) Kumar, R.V. (1998): "Entrepreneurship Development Programme among Women". Centre for Entrepreneurship Developments, 2000, 24 (5), p.5.

5) Coleman, T.P. (2000): The Federal Reserve Board and the United States Small Business Administration.

6) Bindya, B. (2001): Women Entrepreneurship: Challenges and Achievements, NISIET, p.121.

7) Mohanty, A. (2008): Women in Management of Micro Enterprises: Problems and Prospects, Journal of Social Science, 2004, 8 (3), p. 245-251.

8) Parihar, P. and Singh, S.P. (2006): Constraints Faced by Women Entrepreneurs in Jammu. Journal of Extension Education, January- May p.1-2. 